\title{
Determining the Structure of Project Competence of Future Bachelors of Social Work
}

\author{
Kupenko Olena \\ Candidate of Pedagogical Sciences, \\ Associate Professor of the Department of Psychology, Political Science \\ and Socio-Cultural Technologies of Sumy State University
}

\begin{abstract}
In the general structure of competence, the components of theoretical knowledge, transformative activity, moral and spiritual values and self-organization are considered, and two marginal levels are distinguished: a higher level of competence and a minimum acceptable level of competence. Taking into account the specific professional activity of future bachelors of social work, the structure of project competence is detailed as follows. In the theoretical knowledge component, the marginal levels differ in the limited knowledge at the minimum permissible level only by the management aspect, and the cross-sectoral understanding of the concepts of "project" and "project management" - at the highest level of competence. The transformative activities for the highest level of competence include methods for substantiating contradictions, to which the project is directed, determining the ideal end result, formulating a realistic project goal, decomposing the project, executing the project, introspection, as well as methods of managing teamwork. For minimal competence, only certain project management methods are foreseen, in particular, excluding teamwork management methods. In the component of moral and spiritual values, it is obligatory for both levels to act on the basis of the value attitude to the client of social work as a subject of self-government. As part of self-organization component, we consider projects developed by students as means of self-organization of their further transformative professional activity, but a higher level of competence (as opposed to minimum competence) involves taking into account the activities of other students and environmental events.

Keywords: competence, theoretical knowledge, transformative activity, moral and spiritual values, selforganization, higher level of competence, minimum acceptable level of competence, future bachelors of social work, project, project management.
\end{abstract}

The world is changing and making new demands on the education system:

- the increasing amount of information and technology and future specialists have to absorb it, not by expanding the content of the bulk disciplines and increasing the workload, but by ensuring the effectiveness of teachers and students;

- employers express dissatisfaction with the quality of professional training of young professionals, and this should be addressed through dialogue and cooperation of higher education institutions with potential customers of staff and through development of a certain "common language";

- the world is globalizing and in need of harmonization of educational systems, in particular through the Bologna process, implementation of relevant provisions at the university level, 
ensuring the development of a certain "common language" for the description of higher education programs based on the harmonization of educational structures [1];

- in the international educational space, competition between higher education institutions is increasing and entrants demand transparency of the education process and its results and increase their comparability, and graduates want to accelerate the international recognition of their diplomas [1].

The concept of "competence" is also interpreted as a coherent language to describe academic and professional achievements, ensuring the comparability of learning outcomes.

Analysis of recent research and publications. In this article, we will focus on the project competency structure of future bachelors of social work as project competence and project method are often featured in various studies, in particular in the structure of preparation for professional mobility of future social workers (H.A. Ridkodubska), in the classification of research skills of social workers (O.S. Povidaychik), as the basis of professional mentality in the methodological work (L.Z. Rebukha), in the formation of social and legal competence of future social workers (O.V. Lisovets), in psychological formation of the personality of a specialist (V.V. Balakhtar), in health preserving activities of a social worker (L.E. Kloss), in preparation for conflict resolution in professional activity (S.M. Kalaur), and in the professional training of future social workers to work in local communities (H.I. Sozanska).

The purpose of the article. The purpose of the article is to determine the structure of project competence of future bachelors of social work.

Presenting main material. Competence as a whole has a complex structure that has already been sufficiently researched and described. So, in the documents of the European project TUNING the concept of "competence" is revealed as knowledge and understanding (theoretical knowledge of the subject area, the ability to know and understand), knowledge how to act (practical application of knowledge to a specific situation), and knowledge how to be (values as an integral part of perception and living and interacting with others in a social context).

Competence is a system of knowledge in action, and since the acquisition, transformation and use of knowledge implies not only cognitive but also active cognitive activity, emotional- volitional and motivational components are also distinguished in the 
competence structure, but what creates meaning is an activity component - procedural knowledge [2].

Considering the competence approach, I.D. Beh pays particular attention to the concept of "theoretical knowledge", which, unlike empirical, has internal relations, connections, and regularities. Theoretical knowledge involves subjective actions with knowledge that is thinking. Within the competency approach, I.D. Beh calls attention to the need to teach thinking, seeing the way of such learning in dialectics. The learner should be aware that any truth (knowledge) is born in response to a difficult problem that a person faces as a need and contradiction. Any ready-made knowledge is a previously settled contradiction. That is, it is necessary to assimilate not only the ready result of thinking but also the way of thinking by which this result was obtained [3]. I.D. Beh also reveals the content of practical activities in the development of higher level competencies, emphasizes the need to expand the narrow application of fragments of practice as a means of using the learned scientific knowledge, solving practical problems, the criterion of truthfulness of knowledge. The purpose of the competence approach is to ensure a consistent transformation of the subject of learning into a subject of practical activity as a purposeful transformation of reality [3].

The competency-based approach by I.D. Beh includes a person-centered approach. "This educational approach is, first of all, considered as a unit of a person's personal development, which is motivated by a certain moral and spiritual value as a self-worthy form of activity. Therefore, it is only in this educational approach that it is possible to speak without any reservations about the spiritual and practical development of the world by the person, about his moral and spiritual practice in relation to the world of people and the world of things "[3]. Important is the author's indication of the way to implement this approach through joint vocational training.

According to I.D. Beh, "gaining experience requires the management of the teacher not only individually performed student's educational activity but also types of joint vocational training, i.e., interaction of the student with the teacher and peers. It is necessary, because the development of the individual is carried out not only by improving his individual subject activity but also by improving his relationships and types of communication with the environment. It is in the group types of work that " conditions arise for interaction actions, in which the moral and spiritual spheres of the student, his basic sensory-value orientations are 
improved" [3].

Thus, in the structure of competence scientists distinguish components of theoretical knowledge, transformative activity, and moral and spiritual values.

V.I. Baidenko draws attention to the fact that in modern conditions problematic decisions are made and the necessary actions are implemented in complex and dynamic systems; competences can be properly understood and explored in the context of modern theory of self-organization, using synergetics. Abilities, readiness and knowledge are associated with values and realized through volitional impulses by dispositional prerequisites of purposeful behavior under the massive unreliability of decisions [4]. That is, we must also distinguish a component of self-organization in the structure of competence.

It is clear that a person can possess each of these components at one level or another.

I.D. Beh distinguishes two levels of personality competence: 1) lower, when the subject through trial and error or through a mechanism of imitation masks certain practical ways of acting in certain situations, being motivated by the need for cultural (normative) functioning in the social environment. During the formation of the practical skill of modes of action, appropriate empirical knowledge about these methods is assimilated; but there is no theoretical basis for both knowledge and modes of action. The competences of this level are not sufficiently generalized and limited in the transfer of the learned practical ways of action to other objects, limited in view of the specifics of the new circumstances; 2) higher level of competence is based on scientific (theoretical) property; motivation basis of competence of this level is striving for self-affirmation as well as experiencing feelings of dignity and broad social motives [3].

It is important to note that in the US, in the context of society's demands for improving the quality of national education, a minimum competency study is also conducted, that is, not only any level of training is recognized but only one that is not below a certain minimum [5]. Note that we consider minimal competence not in the sense of a lower level of competence of the individual as possessing certain practical ways of acting in a certain limited set of situations, but as a certain level of competence on the basis of theoretical knowledge.

Further, detailing project competence, we will distinguish a level of minimum competence and a higher level of competence in each of its components.

To detail project competence, we refer to the concept of "project activity" and carry 
out its theoretical analysis in the aspect of various sciences.

The project by M.S. Hagan is the perfect image of what is not but what can and should be created [6, p. 359]. According to the scientist, designing activity provides real, material and practical activity with advance and guiding programs. The scientist draws attention "to the first question of any project activity: Do we have guarantees that this ideal image will turn from subjective reality to objective?" [6, p. 159-160]. In practice, it happens that ideas are not implemented precisely because of their low-level competence.

Nowadays, with the mastery of project activity, experts connect the possibilities of solving the issues of planning and realization of certain works, attracting funds from external sources of financing as the best use of their own resources. Let us turn to the definitions of "project" and "project management" activities in the aspect of management. K.F. Gray and E.U. Larson cite the following definition: "A project is a complex, one-step, non-recurring event, limited in time, budget, resources, and clear implementation instructions designed for the needs of the customer" [7, p. 16].

Project Management is the process of managing and coordinating human, material and financial resources throughout the project lifecycle through the use of modern management methods and techniques to achieve the results defined in the project in terms of composition and scope of work, cost, time, and quality, meeting the interests of project participants $[8, \mathrm{p}$. $18]$.

M. Grashina and V. Duncan define project management as an orderly approach to activity in a disordered environment [9, p. 17].

H.M. Tarasyuk in project management identifies issues of team and resource management and draws attention to the availability of specific methods and techniques that ensure the successful achievement of the goal [10, p. 14].

Thus, by distinguishing the component of theoretical knowledge in the structure of project competence, we include in this structure the knowledge about the project as the ideal way of what does not exist but what is needed, and that can be created as a leading and guiding program with appropriate guarantees to achieve a given ideal image. By distinguishing theoretical knowledge about project management activities in the project competence structure, we include in this structure the knowledge about the following characteristics of project activity: focus on achievement of certain results, complexity, non- 
repetitiveness, time constraint, limited budget and other resources, manageability even in conditions of disordered environment, knowledge of clear instructions for execution, and appropriate methods and techniques, including methods and techniques for managing teamwork. Higher level of competence implies having a complete list of this knowledge; for the minimum level of competence, knowledge of methods and techniques of managing teamwork, in our opinion, may be excluded. And at this level, students are allowed to have a minimal set of other methods and techniques of project activity.

Regarding the set of methods and techniques of the higher level of project competence of future bachelors of social work, the previous works of the author substantiate the following: 1) the implementation of factor approach to justify the contradiction, to which decrease the project isdirected; 2) the use of the "magic wand" of H.S. Altshuller to determine the perfect end result; 3) clarification of the realistic idea of the project through SWOT analysis; 4) the use of SMART criteria for formulating the project objective; 5) assessing project completion for all entities and identifying project products; 6) decomposition of the project to determine its activities; 7) implementation of activities on the own-developed project; 8) introspection and report on the results of the project implementation. The following set of methods has been empirically established for the minimum level of project competence of future bachelors of social work: 1) the use of SMART criteria for formulating the purpose of the project; 2) decomposition of the project to determine its activities; 3 ) implementation of activities on the own-developed project; 4) self-examination and project implementation report.

Let us consider the specifics of professional projects of future bachelors of social work. V.A. Lukov defines social design as "the construction of an individual, group or organization of action aimed at achieving socially significant goals and localized by place, time and resources" [11, p. 7]. The scientist emphasizes that "the project's desire for comprehensive results (all-encompassing happiness, etc.) contradicts the peculiarities of the modern world" [11, p. 30]. Local action based on global systemic thinking and knowledge of the target group and social environment is required.

The subject of social design may be: a new thing; new properties of the old thing; service; organization; event; intangible properties or attitudes; a bill [11, p. 37-49]. It has been empirically established that for future bachelors of social work, the subject of projecting a 
higher level of project competence may be a new thing (such as a board game) or an event of a complex nature. For example, our students have created a board game on combating human trafficking, designed and implemented, taking into account the specifics of regional topics and such complex measures as employment hacking, forum of violence, various activities of leisure in the city and outside the city. For the minimum level of project competence of future bachelors of social work, a simple measure may be the subject for social design.

In conclusion, we take into account another specificity of social design. A social worker in his activity proceeds from the fact that receiving assistance in overcoming one crisis state by socially unprotected layers of the population may be accompanied by subsequent crises. If the subjective potential - the internal resources of the people themselves in crisis - can be activated, then the emergence of a certain part of new problems can be prevented, and additional opportunities will be created to overcome others, because according to V.I. Kurbatova and O.V. Kurbatova, consumers of social services "usually have a supply of internal social resources that can be mobilized to solve a particular social problem" [12, p. 9]. However, it is clear that a certain social problem therefore arises, since some people in certain conditions can not (without outside help) become the subject of activity. Therefore, the job of a social worker is to help clients become self-governed.

In the table below we summarize the structure of project competence of future bachelors of social work.

Table 1 - Matrix of components of project competence of future bachelors of social work

\begin{tabular}{|c|c|c|c|}
\hline $\begin{array}{l}\text { Theoretical } \\
\text { knowledge }\end{array}$ & Transformative activity & $\begin{array}{c}\text { Moral and spiritual } \\
\text { values }\end{array}$ & $\begin{array}{c}\text { Self- } \\
\text { organization } \\
\text { and synergy }\end{array}$ \\
\hline \multicolumn{4}{|c|}{ Higher level of competence } \\
\hline $\begin{array}{l}\text { Content of the } \\
\text { concepts of } \\
\text { "project", "project } \\
\text { activity" in aspects } \\
\text { of various sciences }\end{array}$ & $\begin{array}{l}\text { 1) Implementation of factor approach } \\
\text { to justify the contradiction, to which } \\
\text { decrease the project is directed; } \\
\text { 2) use of the "magic wand" of } \\
\text { H.S Altshuller to determine the } \\
\text { perfect end result; } \\
\text { 3) clarification of the realistic idea of }\end{array}$ & $\begin{array}{l}\text { - The ability to act on } \\
\text { the basis of the value } \\
\text { of local action, which } \\
\text { relies on global } \\
\text { thinking; } \\
\text { - the ability to act on } \\
\text { the values of the past, }\end{array}$ & $\begin{array}{l}\text { Own project } \\
\text { analysis and } \\
\text { the results } \\
\text { of its } \\
\text { implementat } \\
\text { ion, taking } \\
\text { into account }\end{array}$ \\
\hline
\end{tabular}




\begin{tabular}{|c|c|c|c|}
\hline & $\begin{array}{l}\text { the project through SWOT analysis; } \\
\text { 4) the use of SMART criteria for } \\
\text { formulating the project objective; } \\
\text { 5) assessing project completion for } \\
\text { all involved entities and thereby } \\
\text { identifying project products; } \\
\text { 6) decomposition of the project to } \\
\text { determine its activities; } \\
\text { 7) implementation of activities on the } \\
\text { own-developed project; } \\
\text { 8) introspection and report on the } \\
\text { results of the project implementation; } \\
\text { methods and techniques of teamwork } \\
\text { management and leadership }\end{array}$ & $\begin{array}{l}\text { present, and future; } \\
\text { - the ability to act } \\
\text { relying on the value- } \\
\text { based attitude } \\
\text { towards a social } \\
\text { work client as a self- } \\
\text { governing entity }\end{array}$ & $\begin{array}{l}\text { activities of } \\
\text { other } \\
\text { students and } \\
\text { events of } \\
\text { the external } \\
\text { environment }\end{array}$ \\
\hline \multicolumn{4}{|c|}{ Minimum permissible competence } \\
\hline $\begin{array}{l}\text { Content of the } \\
\text { concept of } \\
\text { "project", "project } \\
\text { activity" in the } \\
\text { aspect of } \\
\text { management }\end{array}$ & $\begin{array}{l}\text { 1) The use of SMART criteria to } \\
\text { formulate the project objective; } \\
\text { 2) decomposition of the project to } \\
\text { determine its activities; } \\
\text { 3) implementation of activities on the } \\
\text { own-developed project; } \\
\text { 4) introspection and report on the } \\
\text { project implementation results }\end{array}$ & $\begin{array}{l}\text { The ability to act } \\
\text { relying on the value- } \\
\text { based attitude } \\
\text { towards a social work } \\
\text { client as a self- } \\
\text { governing entity }\end{array}$ & $\begin{array}{l}\text { Own project } \\
\text { analysis and } \\
\text { the results } \\
\text { of its } \\
\text { implementat } \\
\text { ion }\end{array}$ \\
\hline
\end{tabular}

Conclusions and prospects of research. Considering the project competence of future bachelors of social work in the article, we proceeded from the allocation in the structure of such competence the components of theoretical knowledge, transformative activity, moral and spiritual values, and self-organization. Taking into account the specific professional activity of future bachelors of social work within this structure, the relevant knowledge, actions and values are detailed both at the highest level of project competence and at the minimum acceptable level. In the component of theoretical knowledge, these levels are distinguished by 
limited knowledge - the aspect of management at the minimum acceptable level of competence, and the intersectoral understanding of the concepts of "project" and "project management" at the higher level of competency. The component of transformative activity for the higher level of competency includes methods of substantiation of contradictions: the project, determining the ideal end result, the formulation of a realistic goal for the project, decomposition of the project, the implementation of the project, introspection as well as methods for managing teamwork are aimed to reduce those contradictions. For minimal competence, only certain project management methods are foreseen, in particular, excluding teamwork management methods. An integral part of moral and spiritual values is required at both levels to be able to act relying on the value-based attitude towards a social work client as a self-governing entity. In the component of self-organization, we consider the projects developed by students as a means of self-organization of their further transformative professional activity within the limits of a certain act, but at the same time a higher level of competence (as opposed to minimum competence) involves taking into account the activities of other students and events of the external environment.

\section{References}

1. Lokhoff, J., Wegewijs, B., Durkin, K., Wagenaar, R., Gonzalez, J., Isaacs, A. K., Dona dalle Rose, L. \& Gobbi, M. (Eds.). A tuning guide to formulating degree programme profiles; Including programme competences and programme learning outcomes. - Universidad de Deusto, Bilbao, Spain, 2010.

2. Zeer E.F., Symanyuk E.E. Kompetentnostnyi podhod k modernizatsii professionalnogo obrazovaniya [Competency-based approach to the modernization of vocational education] // Vysshee obrazovaniye v Rossii, 2005. № 4, P. 23-30.

3. Beh I.D. Kompetentnisnii pidhid yak osvitnya strategiya [Competency approach as an educational strategy]. URL: https://core.ac.uk/download/pdf/32308232.pdf

4. Baidenko V.I. Kompetentsii v professionalnom obrazovanii (K osvoeniyu kompetentnostnogo podhoda) [Competencies in vocational education (Towards mastering the competency approach)] // Vysshee obrazovanie v Rossii, 2004. № 4, P. 3-13. URL: https://cyberleninka.ru/article/n/kompetentsii-v-professionalnom-obrazovanii-k-osvoeniyukompetentnostnogo-podhoda

5. Lokshina O.I. Monitoring rivniv dosyagnen kompetentnostei: innovatsyini pidhody [Monitoring the levels ofcCompetency achievement: Innovative approaches] // Kompetentnisnii pidhid u suchasnii osviti: svitovyi dosvid ta ukrayinski perspektyvy: Biblioteka z osvitniyi polityky / O.V. Ovcharuk (ed). - K.I.S., Kyiv, Ukraine. 2004. P. 25-32.

6. Kagan M.S. Sistemnyj podhod i gumanitarnoe znaniye [Systems approach and 
humanitarian knowledge]. Izdatelstvo Leningradskogo universiteta, Leningrad, Russia, 1991.

7. Grey K.F., Larson E.U. Upravlenie proektami : Prakticheskoye rukovodstvo [Project management: A Practical guide]. - Delo i Servis, Moscow, Russia. 2003.

8. Moskvin S.O., Bevz S.M., Verba V.A. et al. Proektnyi analiz: Navchalnyi posibnyk [Project Analysis: Tutorial] / S.O. Moskvin (ed.). - TOV "Vidavnitstvo Libra", Kyiv, Ukraine, 1999.

9 Grashina M.N., Dunkan V.R. Osnovy upravleniia proektami [Project Management Basics]. - Piter, St. Petersburg, Russia, 2006.

10. Tarasiuk G.M. Upravlinnia proyektami: Navchalnyi posibnyk dlia studentiv vyshih navchalnyh zakladiv [Project management: Tutorial for university students]. - Karavela, Kyiv, Ukraine, 2004.

11. Lukov V.A. Sotsialnoye proyektirovaniye [Social design]. - Izdatelstvo Moskovskogo gumanitarnogo universiteta: Flinta, Moscow, Russia, 2004.

12. Kurbatov V.I., Kurbatova O.V. Sotsialnoye proyektirovaniye : Uchebnoye posobiye [Social design: Tutorial]. - Feniks, Rostov-on-Don, Russia, 2001. 